\title{
Metformin Induces Apoptosis and Alters Cellular Responses to Oxidative Stress in Ht29 Colon Cancer Cells: Preliminary Findings
}

\author{
Paola Sena ${ }^{1}$ (1), Stefano Mancini ${ }^{2}$, Marta Benincasa ${ }^{1}$, Francesco Mariani ${ }^{2}$, Carla Palumbo ${ }^{1}$ (b) \\ and Luca Roncucci ${ }^{2, *(1)}$ \\ 1 Department of Biomedical, Metabolic and Neurosciences, Section of Human Morphology, University of \\ Modena and Reggio Emilia, Policlinico, Via Del Pozzo 71, I-41125 Modena, Italy; \\ paola.sena@unimore.it (P.S.); marta.benincasa@unimore.it (M.B.); carla.palumbo@unimore.it (C.P.) \\ 2 Department of Diagnostic and Clinical Medicine, and Public Health, University of Modena and Reggio \\ Emilia, Policlinico, Via Del Pozzo 71, I-41125 Modena, Italy; mancini77@cloud.com (S.M.); \\ francesco.mariani@unimore.it (F.M.) \\ * Correspondence: luca.roncucci@unimore.it; Tel.: +39-0594224052
}

Received: 20 March 2018; Accepted: 10 May 2018; Published: 16 May 2018

\begin{abstract}
Accumulating evidence suggests that metformin, used as an antidiabetic drug, possesses anti-cancer properties. Metformin reduced the incidence and growth of experimental tumors in vivo. In a randomized clinical trial among nondiabetic patients, metformin treatment significantly decreased the number of aberrant crypt foci compared to the untreated group with a follow-up of 1 month. In our study, HT29 cells were treated with graded concentrations of metformin, $10 \mathrm{mM} / 25 \mathrm{mM} / 50 \mathrm{mM}$ for $24 / 48 \mathrm{~h}$. We performed immunofluorescence experiments by means of confocal microscopy and western blot analysis to evaluate a panel of factors involved in apoptotic/autophagic processes and oxidative stress response. Moreover, HT29 cells treated with metformin were analyzed by a flow cytometry assay to detect the cell apoptotic rate. The results demonstrate that metformin exerts growth inhibitory effects on cultured HT29 cells by increasing both apoptosis and autophagy; moreover, it affects the survival of cultured cells inhibiting the transcriptional activation of Nuclear factor E2-related factor 2 (NRF-2) and nuclear factor-kappa B (NF-KB). The effects of metformin on HT29 cells were dose- and time-dependent. These results are very intriguing since metformin is emerging as a multi-faceted drug: It has a good safety profile and is associated with low cost and might be a promising candidate for the prevention or the treatment of colorectal cancer.
\end{abstract}

Keywords: colorectal cancer cells; metformin; apoptosis; oxidative stress

\section{Introduction}

Colorectal cancer (CRC) is still a major neoplasm [1], and its prevalence and mortality have a high impact on human health [2]. A paradigm shift from surveillance and early detection of cancer or adenomas to new preventive strategies, including chemoprevention, is necessary to lower the burden of this disease. Several large epidemiologic and clinical studies have evaluated the possible effects of more than 200 agents, including fibers, calcium, and nonsteroidal anti-inflammatory drugs such as 5-aminosalicylic acid and selective cyclooxygenase-2 (COX-2) inhibitors, in preventing CRC development [3]. Nonsteroidal anti-inflammatory drugs, especially COX-2 inhibitors alone or in combination, have shown the most promise for CRC risk reduction [4], but an increased risk of serious cardiovascular events associated with COX-2 inhibitor use has been reported $[5,6]$. Thus, novel drugs that would be both safe and effective are needed for CRC prevention. CRC is associated 
with lifestyle-related diseases such as diabetes and obesity [7-10]; these conditions might represent new targets for CRC chemoprevention. Metformin (1,1-dimethylbiguanide hydrochloride) is a biguanide derivative that has been extensively used for treating diabetes mellitus [11]. It decreases basal glucose output by suppressing gluconeogenesis and glycogenolysis in the liver, and by increasing glucose uptake in muscle tissue. Because metformin does not directly stimulate insulin secretion, the risk of hypoglycemia associated with its use is lower than that associated with the use of other oral antidiabetic drugs [12]. The mechanism of action of metformin involves liver kinase B1-dependent activation of AMP-activated protein kinase [13]. Patients with type 2 diabetes taking metformin might be at a lower risk of cancer (including CRC), compared with those who do not take metformin $[14,15]$. This evidence suggests that metformin might be a candidate agent for the chemoprevention of CRC in diabetic patients. In a number of preclinical studies, metformin reduced cell proliferation, induced apoptosis, caused cell cycle arrest, and reduced incidence and growth of experimental tumors in vitro and in vivo $[16,17]$. Some reports also indicate that metformin improved the response of human breast tumor xenografts to conventional chemotherapy by eradicating cancer stem cells in the tumor $[18,19]$. HT-29 is a human colorectal adenocarcinoma cell line with epithelial morphology and represents a xenograft tumor model for colorectal cancer. Nuclear factor E2-related factor 2 (NRF-2) is a transcription factor that controls the expression of a large pool of antioxidant and cytoprotective genes regulating the cellular response to oxidative and electrophilic stress. Mutations in the NRF-2 gene, common in cancer cells, could help tumor cells to survive, and might be associated with poor survival of cancer patients. Previous studies have shown that the NRF-2 signaling pathway is abnormally activated in CRC. NF- $\mathrm{KB}$ plays a major role in linking inflammation to cancer development through its ability to upregulate several inflammatory and tumor promoting cytokines, such as IL-6, IL-1 $\alpha$, and Tumor Necrosis Factor $\alpha(\mathrm{TNF} \alpha)$, as well as genes like $B C L 2$ and $B C L X L$. Furthermore, NF- $\mathrm{kB}$ plays an important role in type 2 diabetes mellitus (T2DM), as obesity activates the transcription factor NF- $\mathrm{KB}$, which increases the risk for T2DM. Collectively, NF- $\mathrm{KB}$ could be considered as the matchmaker between inflammation, inflammatory bowel diseases (IBD), cancer, and diabetes [20]. The present study aims to assess whether metformin has the potential to suppress the growth of colorectal cancer cells and to evaluate its role in affecting the NRF-2/NF- $\mathrm{kB}$ pathways.

\section{Results}

\subsection{Metformin Suppresses the Proliferation of HT29 Cells in a Dose- and Time-Dependent Manner}

In order to examine whether metformin affects human colorectal cancer cell proliferation, we investigated the effect of the drug on the cancer cell line HT29 cells. Cells were grown in $10 \%$ fetal bovine serum (FBS) and treated with increasing amount of metformin $(0,10,25$, and $50 \mathrm{mmol} / \mathrm{L})$. The immunofluorescence analysis was performed after the addition of the agents for 24 and $48 \mathrm{~h}$, to characterize the time-dependent impacts of metformin.

The first observation was made using an inverted microscope and raised concerns about the eventual changes of some features (viability, adhesion, and morphology) of the treated cells compared to controls; as shown in Figure 1 the phenotype of HT29 cells treated with metformin was preserved, although the cell adhesion to the culture plates implied some changes in the characteristic rounded shape of untreated HT29 cells Figure 1. 


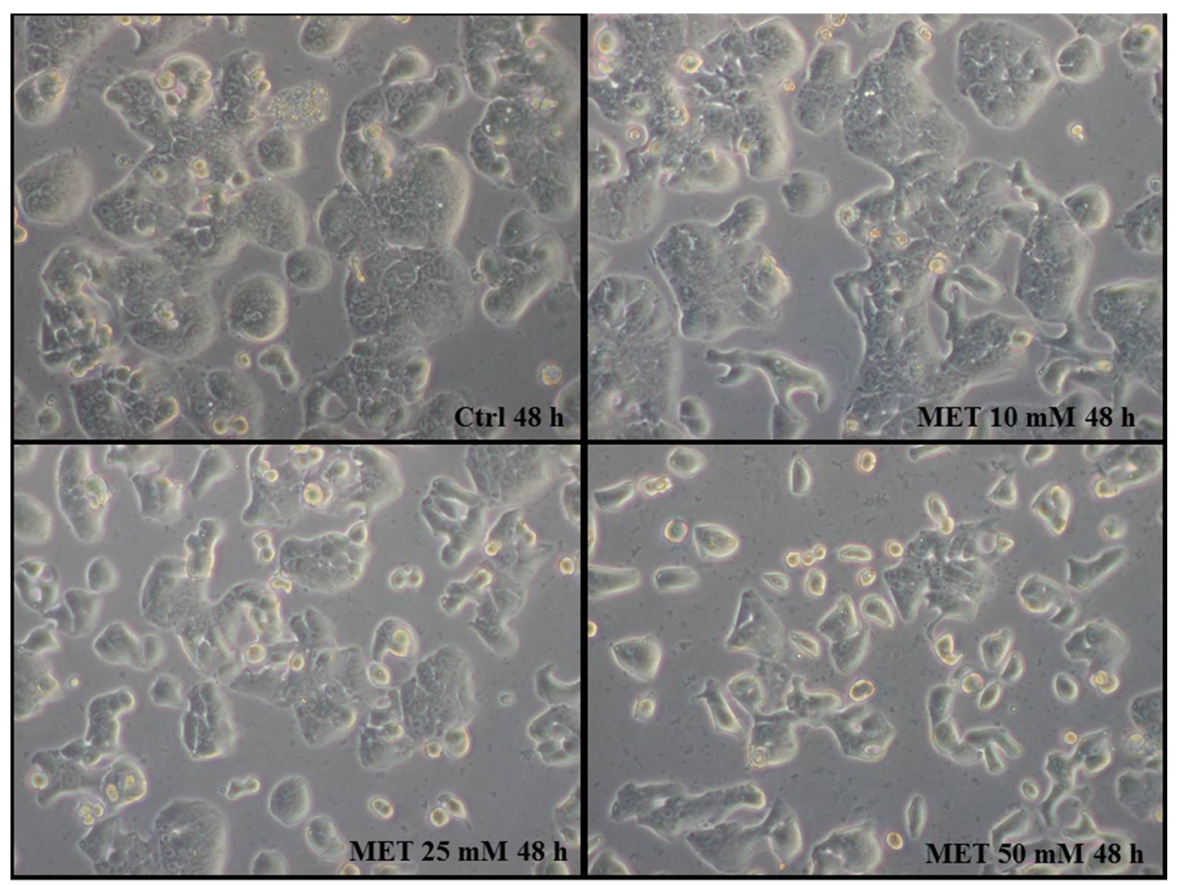

Figure 1. Inverted microscope image of HT29 cells treated with graded concentrations of metformin, $10 \mathrm{mM} / 25 \mathrm{mM} / 50 \mathrm{mM}$ for $24 \mathrm{~h}$ and $48 \mathrm{~h}$; and of untreated cells (CTRL). The phenotype of HT29 cells treated with metformin was preserved, although cell adhesion to the culture plates caused some changes in the characteristic rounded shape of untreated HT29 cells. Magnification $40 \times$.

This modification of cell morphology is probably due to the partial loss of plasma membrane attachment, these features are characteristic of the earliest phases of the apoptotic process. Cell counting showed that metformin caused a strong anti-proliferative effect at a dose of $10 \mathrm{mM}$ for $24 \mathrm{~h}$; the effect was slight, but significant anti-proliferative action was observed with higher doses for $24 \mathrm{~h}$ or $48 \mathrm{~h}$. The counting obtained was the following, $43 \%, 52 \%$, and $65 \%$ inhibition for $10 \mathrm{mM}, 25 \mathrm{mM}$, and $50 \mathrm{mM}$, respectively, compared with controls after $24 \mathrm{~h}$ treatment; $45 \%, 61 \%$, and $68 \%$ inhibition for $10 \mathrm{mM}$, $25 \mathrm{mM}$, and $50 \mathrm{mM}$, respectively, compared with controls after $48 \mathrm{~h}$ treatment.

To confirm these preliminary data, immunofluorescence experiments, coupled with confocal analysis, were performed using a panel of antibodies to determine the effect of metformin treatment on the expression profile of autophagy/apoptosis or proliferation markers.

The Ki-67 protein was used as a marker for cell proliferation and the results from the immunofluorescence analysis Figure 2, and showed that metformin significantly downregulates the expression of Ki-67 and nuclear localization in a time- and dose-dependent manner.

The treatment at $48 \mathrm{~h}$ with MET $50 \mathrm{mM}$ caused a maximum decrease of $45 \%$ in the proliferation index, as reported in Table 1, which collects data of semi-quantitative evaluation of immunostaining intensity (Immunofluorescence Intensity Score: IFIS).

Table 1. Evaluation of immunostaining intensity (Immunofluorescence Intensity Score: IFIS).

\begin{tabular}{|c|c|c|c|c|c|c|c|c|}
\hline \multirow{2}{*}{ Proteins } & \multicolumn{4}{|c|}{ IFIS (Mean \pm SD)-24 h } & \multicolumn{4}{|c|}{ IFIS (mean \pm SD)-48 h } \\
\hline & CTRL & $10 \mathrm{mM}$ & $25 \mathrm{mM}$ & $50 \mathrm{mM}$ & CTRL & $10 \mathrm{mM}$ & $25 \mathrm{mM}$ & $50 \mathrm{mM}$ \\
\hline PARP-1 & $20.0 \pm 4.3$ & $47.0 \pm 11.0$ & $63.0 \pm 9.8$ & $76.0 \pm 15.0$ & $23.0 \pm 12.0$ & $55.0 \pm 6.7$ & $74.0 \pm 13.0$ & $89.0 \pm 22.0$ \\
\hline APAF-1 & $31.0 \pm 7.5$ & $54.0 \pm 3.9$ & $66.0 \pm 19.0$ & $85.0 \pm 9.5$ & $27.0 \pm 7.0$ & $72.0 \pm 17.0$ & $72.0 \pm 17.0$ & $93.0 \pm 12.0$ \\
\hline MAP-LC3 & $26.0 \pm 4.7$ & $45.0 \pm 7.2$ & $71.0 \pm 7.6$ & $93.0 \pm 15.0$ & $28.0 \pm 8.3$ & $57.0 \pm 6.3$ & $84.0 \pm 5.4$ & $103.0 \pm 32.0$ \\
\hline NRF-2 & $55.0 \pm 7.2$ & $43.0 \pm 6.3$ & $31.0 \pm 4.8$ & $19.0 \pm 3.7$ & $63.0 \pm 12.0$ & $47.0 \pm 5.4$ & $30.0 \pm 7.5$ & $23.0 \pm 3.0$ \\
\hline NF-KB & $60.0 \pm 9.5$ & $54.0 \pm 8.3$ & $47.0 \pm 15.0$ & $32.0 \pm 7.4$ & $67.0 \pm 5.7$ & $50.0 \pm 17.0$ & $33.0 \pm 2.0$ & $25.0 \pm 2.9$ \\
\hline
\end{tabular}

$p<0.05$ between all group pairs. 


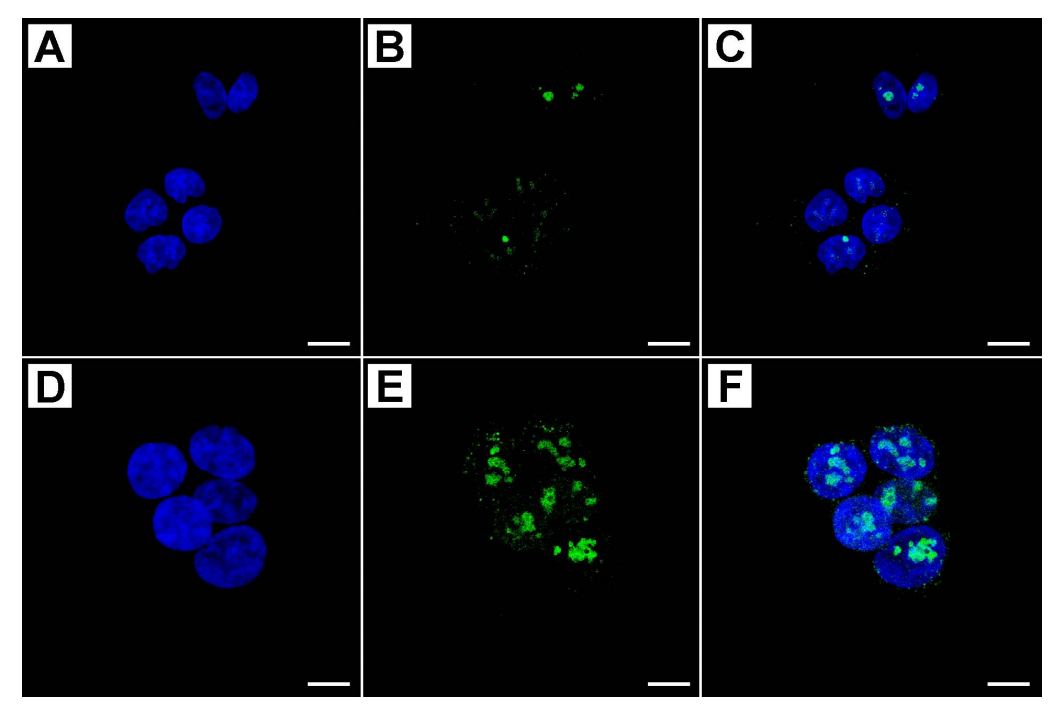

Figure 2. Confocal analysis of Ki-67 protein in treated and untreated cells with graded concentrations of metformin (blue: DAPI; Green: Ki-67; (C,F): merge). Cells that were treated with $10 \mathrm{mM}$ MET for $48 \mathrm{~h}$ showed a weak immunostaining at the nuclear level $(\mathbf{A}-\mathbf{C})$, whereas untreated cells resulted very marked (D-F). Scale bar $=8 \mu \mathrm{m}$.

Furthermore, immunofluorescence analysis was conducted using apoptotic and autophagic specific markers in order to determine whether the inhibitory effect of metformin on colorectal cancer cells was associated with triggering programmed cell death or autophagy.

Using these techniques, we evaluated both qualitatively and quantitatively Cleaved PARP-1, APAF-1, Caspase-3, and MAPLC3 protein expression. Figure 3 shows the co-immunostaining of Cleaved PARP-1 and Caspase-3.

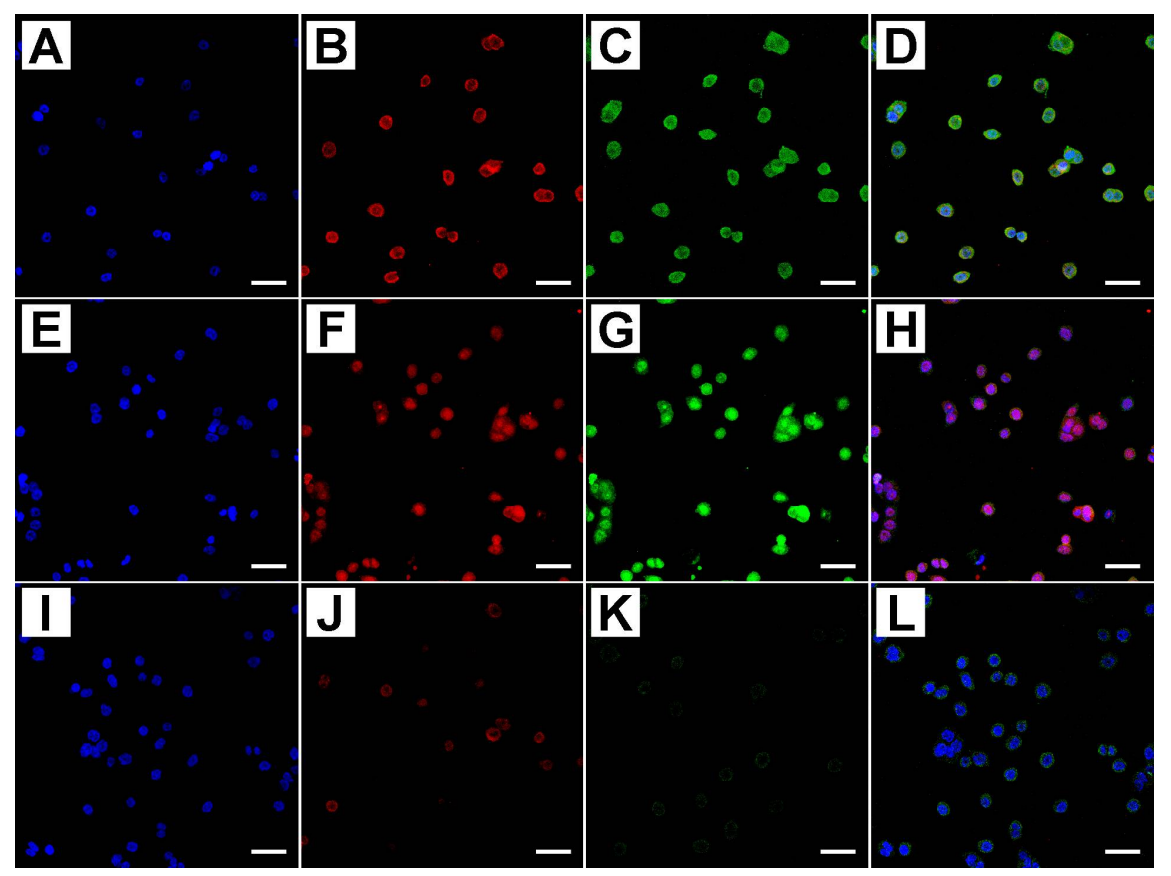

Figure 3. Confocal analysis of PARP-1 and Caspase-3 active proteins in treated and untreated cells with different concentrations of metformin (blue: DAPI; Red: PARP-1 Green: Caspase-3 active; (D,H,L): merge). Cells that were treated with $10 \mathrm{mM}$ MET for $24 \mathrm{~h}$ showed a strong immunostaining for both proteins (A-D), as well as cells treated with $25 \mathrm{mM}$ MET for $24 \mathrm{~h}(\mathbf{E}-\mathbf{H})$. Untreated cells showed a significant decrease in PARP-1 and Caspase-3 active protein expression (I-L). Scale bar $=15 \mu \mathrm{m}$. 
Cleaved PARP-1 antibody detects endogenous levels of the large fragment (89 KDa) of the human protein resulting from cleavage of the native protein and does not recognize the full length PARP-1 or other isoforms. Cleaved PARP-1 was detectable in the nucleus of treated HT-29 cells; however, it is not appreciable in untreated cells Figure 3K. Some representative staining patterns are shown in Figure 3A-D where nuclear labeling of apoptotic cells is evident, as revealed by DAPI staining. Caspase-3 was aggregated in small clumps distributed in the cytoplasm of cultured treated cells, both proteins showed an increased expression pattern related to the dose and time of metformin treatment, as shown in Figure 3A-H. Untreated cells were negative for immunostaining Figure 3I-L.

Figure 4 shows the immunostaining of APAF-1 and MAPLC3.

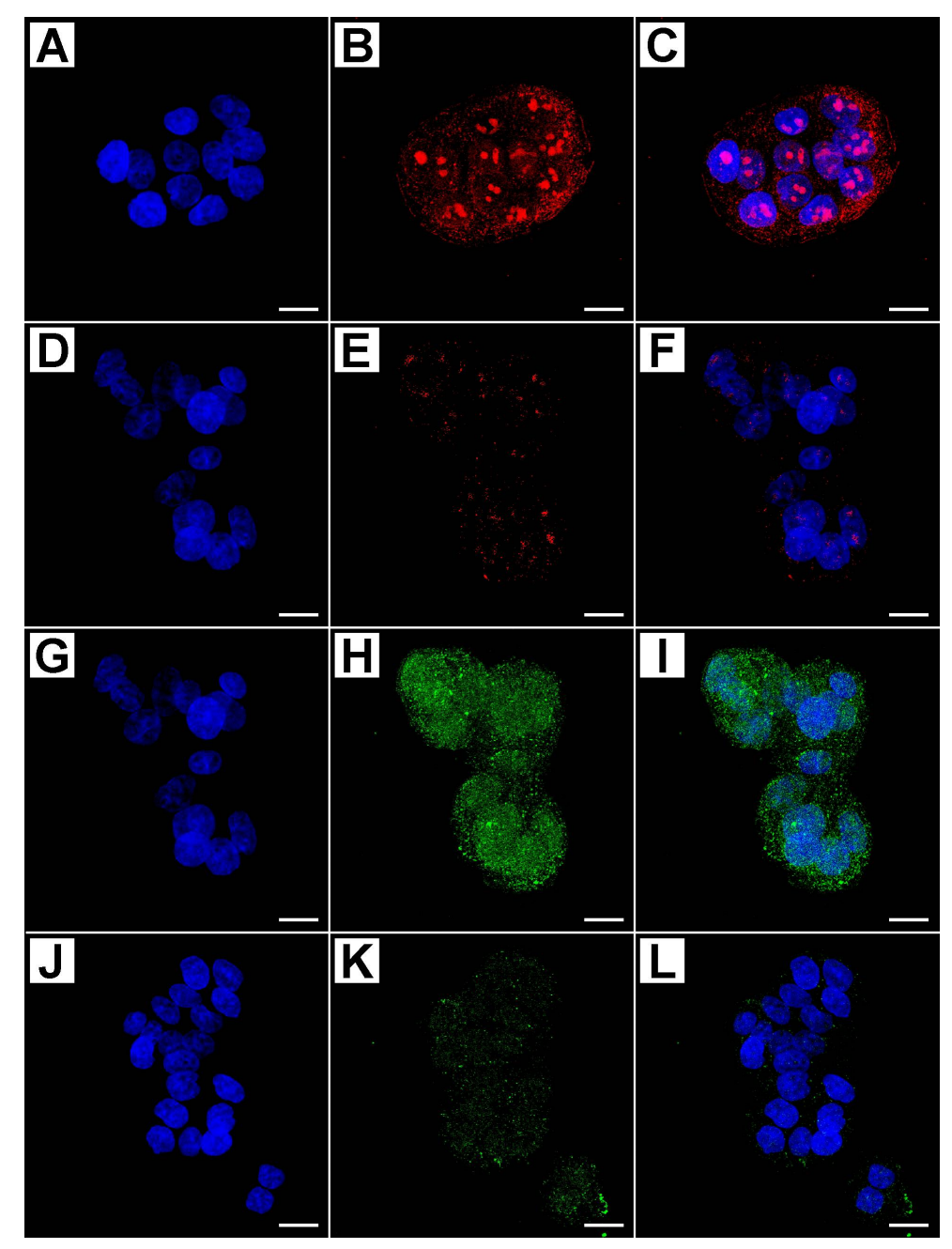

Figure 4. Confocal analysis of APAF-1 and MAPLC3 proteins in treated and untreated cells with different concentrations of metformin (Blue: DAPI; Green: MAPLC3; Red: APAF-1; (C,F,I,L): merge). In treated cells with $50 \mathrm{mM}$ MET for $48 \mathrm{~h}$, APAF-1 showed a diffuse or granular staining pattern at the nuclear level (A-C), while in untreated cells nuclear expression was barely detectable (D-F). In treated cells with $50 \mathrm{mM}$ MET for $48 \mathrm{~h}$ MAPLC3 protein there were two distinct autophagic patterns: A diffuse finely and granular reactivity dispersed in the cytoplasm, or a rounded densely stained material, probably enclosed within a cytoplasmic vacuole that accumulates prevalently around the nucleus $(\mathbf{G}-\mathbf{I})$; untreated cells were very weakly marked $(\mathbf{J}-\mathbf{L})$. Scale bar $=10 \mu \mathrm{m}$.

The staining patterns of the first protein varied from diffuse to granular in the nucleus of treated cells; on the other hand, cells expressing MAPLC3 protein showed two distinct autophagic patterns: diffuse fine and granular reactivity was dispersed in the cytoplasm, or a rounded densely stained 
material, which was probably enclosed within a cytoplasmic vacuole that accumulates prevalently around the nucleus (Figure 4G-I).

The dense rounded autophagic vacuoles were well recognizable in cells treated with higher doses and for longer time; such structures varied in size and density, but usually formed coarse, rather than fine, granules. Untreated cells showed a weak marking for both proteins Figure 4D-F,J-L.

The semiquantitative evaluation of immunostaining intensity, reported as the Immunofluorescence Intensity Score (IFIS) in Table 1, showed that the level of cleaved PARP-1, Caspase-3, APAF-1, and MAPLC3 proteins had an increasing trend in a dose- and time-dependent manner, with statistical significance of the different expression among the groups of treated cells, and with respect to untreated cells.

Moreover, to corroborate the findings of the morphological evaluation previously described, cell lysates of cultured treated and untreated cells were subjected to western blot analysis. As shown in Figure 5, protein bands immunopositive for APAF-1, Cleaved PARP-1, MAPLC3, and caspase-3 were clearly evident in treated cells.

MET 24h MET 48h

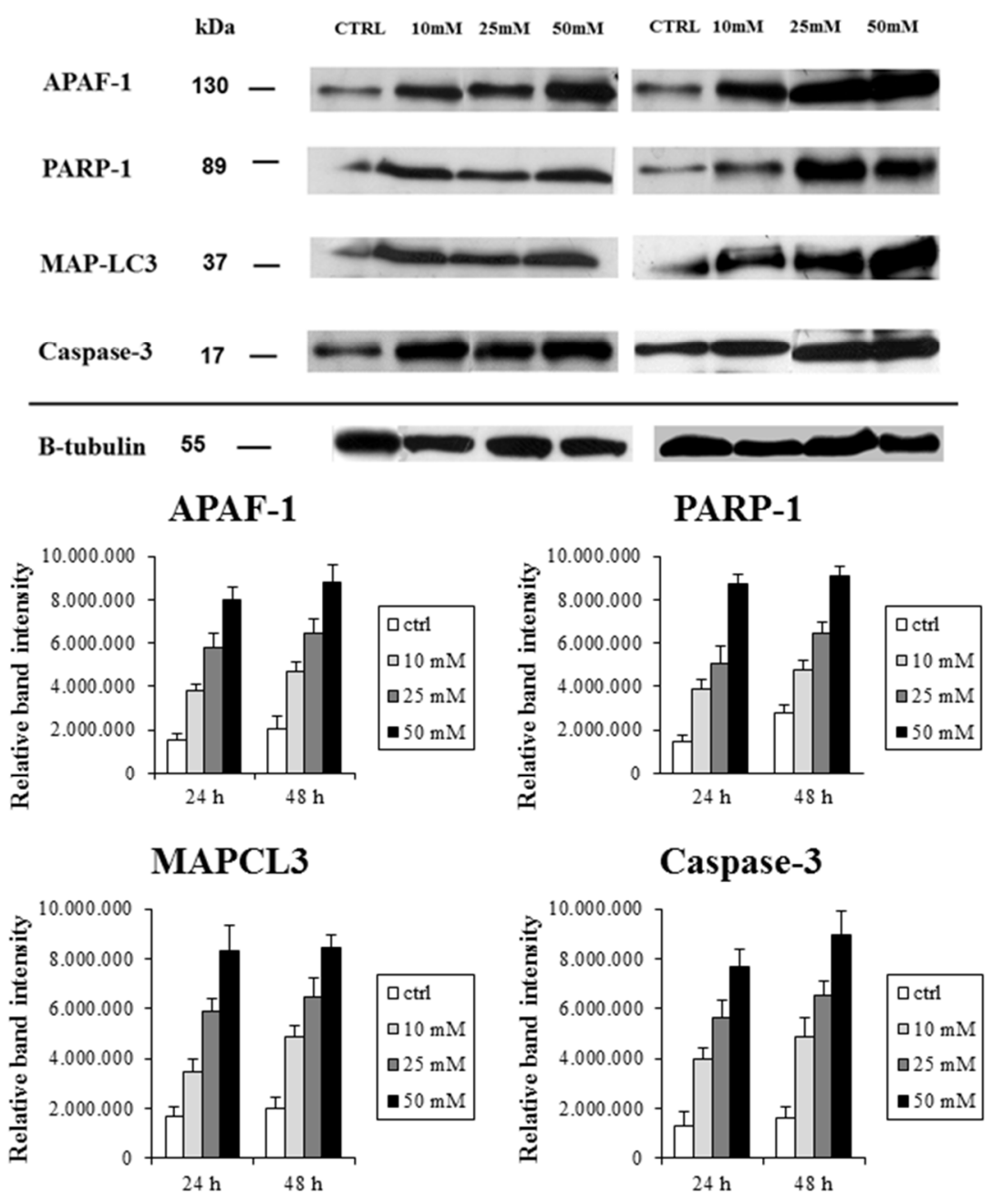

Figure 5. Western blot analysis of HT29 cells treated with graded concentrations of metformin, $10 \mathrm{mM} / 25 \mathrm{mM} / 50 \mathrm{mM}$ for $24 \mathrm{~h}$ and $48 \mathrm{~h}$; and of untreated cells (CTRL), using anti-APF-1, PARP-1, MAPLC3, and Caspase-3 antibodies. Mean densitometric data of APAF-1, PARP-1, MAPLC3, and Caspase- 3 expressions were analyzed using NIH Image J software. $p<0.05$ between all group pairs. 
Lysates of untreated cells generally yielded only a faint band for all these markers. Densitometric analysis and normalization (with equal amounts of protein loading) of the immunoreactivity signals from protein extracts of treated and untreated cells showed that the expression pattern had an increasing trend related to the dose- and time- of treatment. Western blotting and densitometric analysis were performed in triplicate; the quantification of protein expressions between different groups of treatment and respect to the untreated group achieved statistical significance.

\subsection{Metformin Alters NRF-2 and NF- $k B$ Expression in HT29 Cells in a Dose- and Time-Dependent Manner}

Confocal analysis was conducted on HT29 cells treated with increasing amount of metformin $(0,10,25$, and $50 \mathrm{mmol} / \mathrm{L})$, as described above, to analyze the expression pattern of NRF- 2 and NF- $\mathrm{KB}$ proteins. The results demonstrated that metformin affects survival of cultured cells inhibiting the transcriptional activation of NRF-2 and NF- $\mathrm{kB}$. In Figure 6A-C the presence of NRF-2 at the nuclear level in untreated cells is clearly evident, as a consequence of the translocation of the transcriptional factor into the nucleus; in particular, nucleolar domains appeared strongly marked Figure 6B.

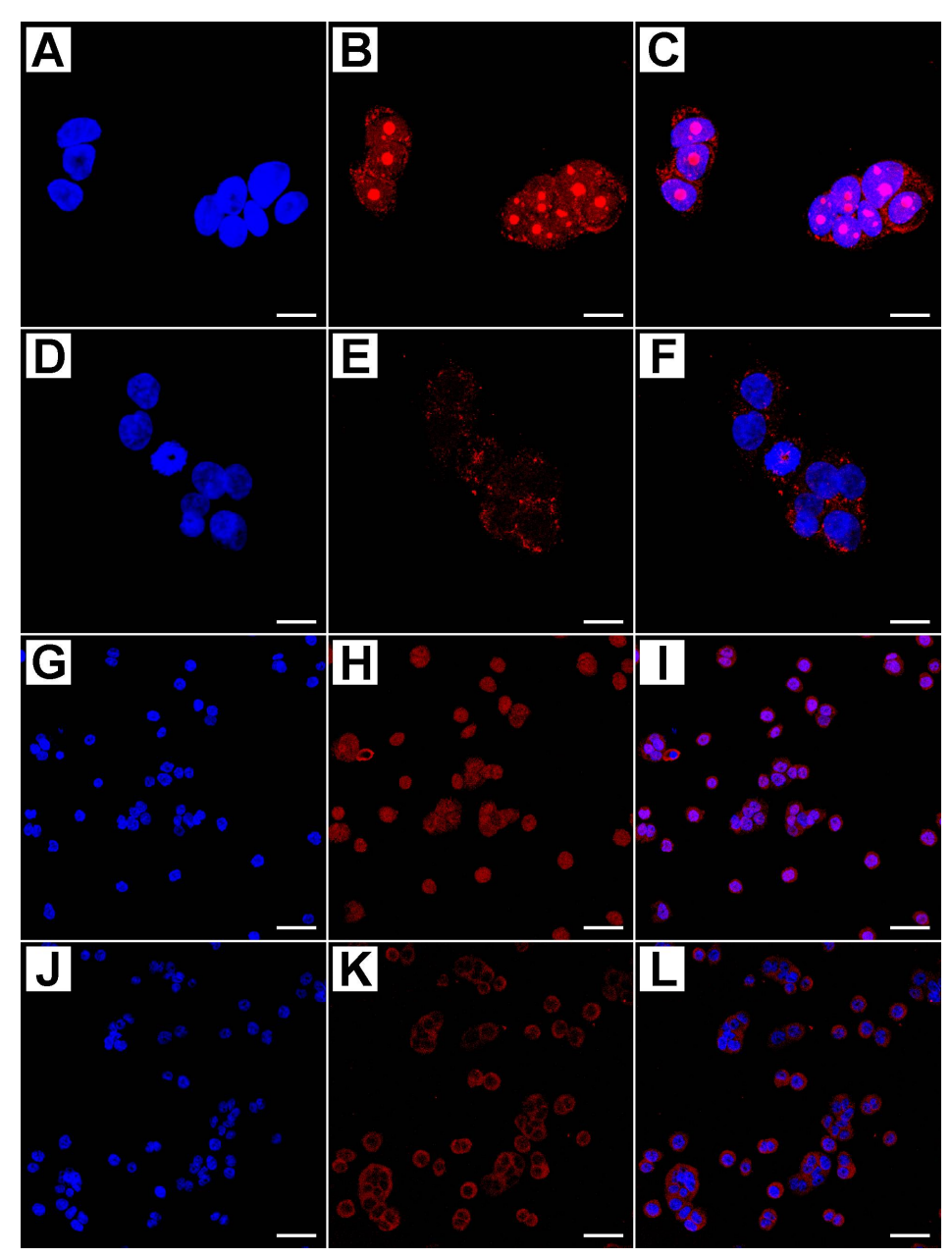

Figure 6. Confocal analysis of NRF-2 and NF- $\kappa \mathrm{B}$ proteins in treated and untreated cells with graded concentrations of metformin (Blue: DAPI; Red: NRF-2, and NF- $\mathrm{BB}$; $(\mathbf{C}, \mathbf{F}, \mathbf{I}, \mathbf{L})$ : merge). NRF-2 clearly showed a strong nuclear reactivity in untreated cells (A-C), whereas in cells treated with $25 \mathrm{mM}$ MET for $24 \mathrm{~h}$ the reactivity was finely dispersed only in the cytoplasmic compartment (D-F). NF- $\mathrm{BB}$ showed a significant translocation into the nucleus in untreated cells with $25 \mathrm{mM} \mathrm{MET}$ for $24 \mathrm{~h}$ (G-I), while in treated cells the protein was scattered in the cytoplasm $(\mathbf{J}-\mathbf{L})$. Scale bar $=10 \mu \mathrm{m}$. 
Treated cells showed a well detectable presence of this protein in the cytoplasm, while the nuclei were slightly marked Figure 6D-F. The effects of metformin on HT29 cell were dose- and time-dependent, because there was a significant change in the parameters analyzed after $48 \mathrm{~h}$ of treatment compared to $24 \mathrm{~h}$, see Table 1.

NF- $\mathrm{KB}$ protein showed a very intense immunostaining in the nuclear compartment in untreated samples, while the cytoplasm was less stained, see Figure 6G-I. In treated cells, the presence of this protein was appreciable only in the cytoplasmic compartment and the staining was evenly distributed throughout the cell Figure 6J-L. The semi-quantitative evaluation of immunostaining intensity (IFIS) in Table 1 showed that the level of NRF-2 and NF- $\mathrm{KB}$ proteins had a decreasing trend in a dose- and time-dependent manner, with statistical significance of the different expressions among the groups of treated cells with respect to the untreated ones.

Western blot analysis showed that NRF-2 expression decreased after treatment with increasing concentrations of metformin. This observation was more evident after $48 \mathrm{~h}$ of treatment. The expression pattern of NF- $\mathrm{KB}$ was slightly different, and the protein amount decreased with higher doses of metformin with respect to NRF-2, Figure 7.

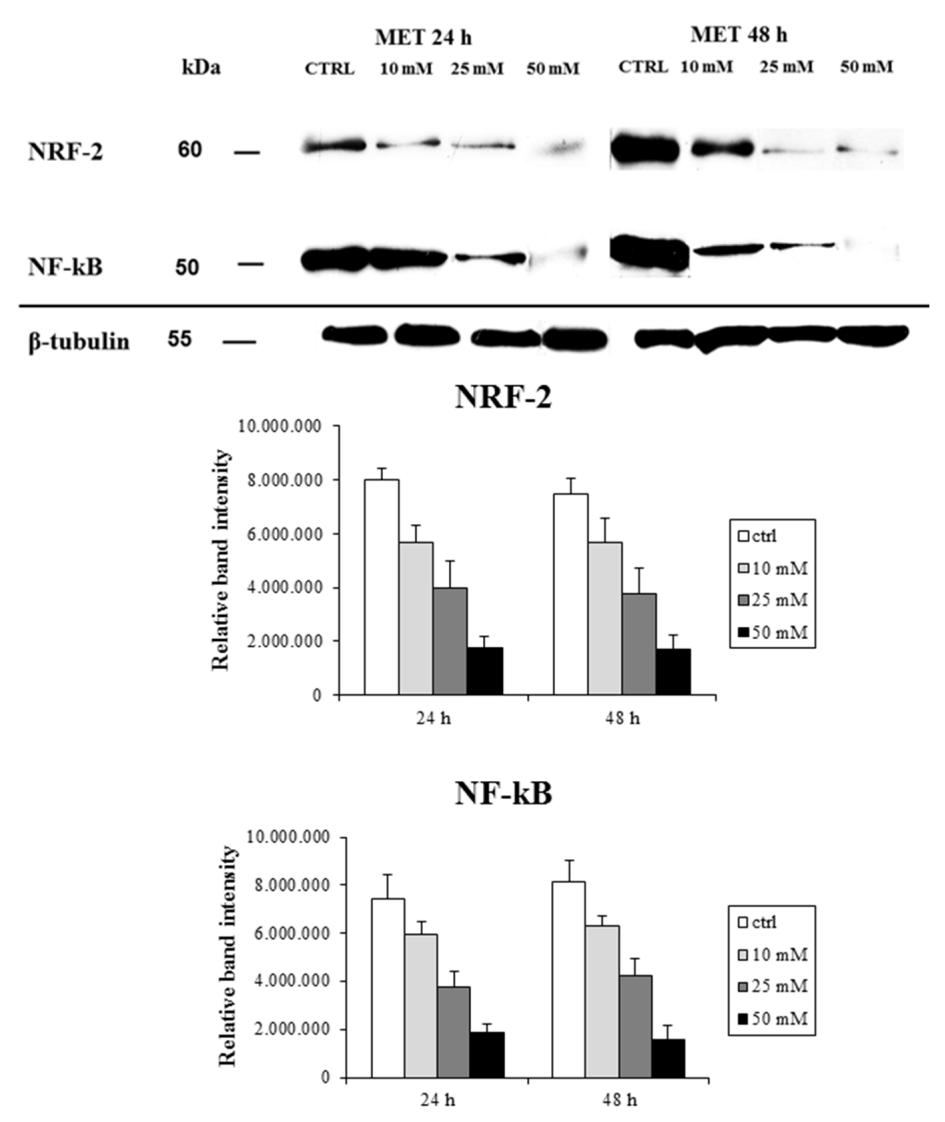

Figure 7. Western blot analysis of HT29 cells treated with graded concentrations of metformin, $10 \mathrm{mM} / 25 \mathrm{mM} / 50 \mathrm{mM}$ for $24 \mathrm{~h}$ and $48 \mathrm{~h}$, and untreated cells (CTRL), using anti-NRF-2 and antiNF- $\mathrm{BB}$ antibodies. Mean densitometric data of NRF-2 and NF- $\mathrm{B}$ expressions were analyzed using NIH ImageJ software. $p<0.05$ between all group pairs.

Densitometric analysis and normalization (with equal amounts of protein loading) of the immunoreactivity signals from protein extracts of treated and untreated cells showed that the expression pattern had a decreasing trend related to the dose and time of treatment. Western blotting and densitometric analysis were performed in triplicate; the quantification of protein expressions between different groups of treatment and the untreated group achieved statistical significance. 
2.3. Flow Cytometry Analysis Demonstrates That Metformin Exerts an Inhibitory Effect on HT29

\section{Cells Survival}

The ability of Metformin treatment to induce apoptosis in HT-29 cells was determined using an Annexin V-FITC assay to establish the relationship between antiproliferation and apoptosis.

Staining with FITC Annexin V clearly showed that the percentage of apoptotic HT29 cells treated with metformin increased in a time- and dose-dependent manner, when comparing treatments to each other. Similarly, the early apoptotic death rate of the HT-29 cells treated with MET was remarkably higher than the controls Figure 8A,B. The highest rate of apoptotic cells (i.e., 60\%) was achieved with the $50 \mathrm{mM}$ treatment for $48 \mathrm{~h}$, Figure $8 \mathrm{~B}$. Flow cytometry analyses were performed in triplicate and the results, which reached statistical significance, agreed with those obtained by the confocal microscopy analysis and western blot experiments.

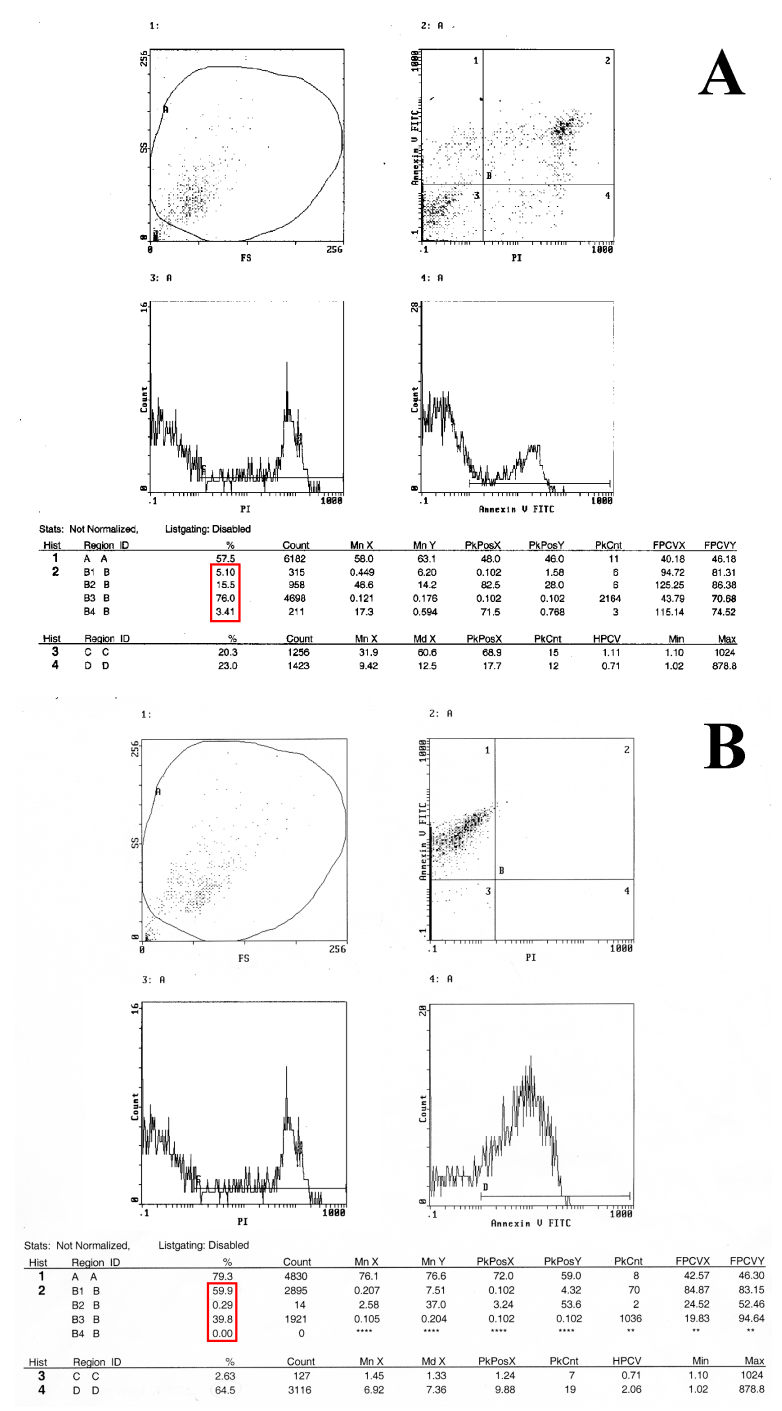

Figure 8. Flow cytometry analysis of untreated (A) and treated (B) cells with graded concentrations of metformin, using an Annexin V-FITC assay. (A) The early apoptotic death rate of untreated HT-29 cells was $5.1 \%$ (line 2, third column of the Table below the Figure). (B) The early apoptotic death rate of the HT-29 cells treated with MET was remarkably higher than the control. The highest rate of apoptotic cells was achieved with the $50 \mathrm{mM}$ treatment for $48 \mathrm{~h}$, i.e., $59.9 \%$ (line 2, third column of the Table below the Figure). In the red box are evident the apoptotic rates for untreated (panel A), and metformin treated (panel B) cells 


\section{Discussion}

In this study, HT29 cells were treated with different concentrations of metformin, $10 \mathrm{mM} / 25 \mathrm{mM} / 50 \mathrm{mM}$ for 24 and $48 \mathrm{~h}$. We performed immunofluorescence experiments by means of confocal microscopy and western blot analysis to evaluate a panel of factors involved in apoptotic/autophagic processes and oxidative stress response. Moreover, HT29 cells treated with metformin were analyzed by flow cytometry assay to detect the apoptotic rate of the cells. The first observations concerning the phenotype of HT29 cells treated with metformin showed modifications of cell morphology, probably due to the partial loss of plasma membrane attachment; these features are characteristic of the earliest phases of the apoptotic process. The immunofluorescence analysis of Ki-67 expression pattern corroborates this finding; in fact, there was a strong decrement of Ki-67 protein in treated cells with respect to the untreated ones. All these results were related to dose and time of treatment. Moreover, the apoptotic-inducing activities of metformin causes an increase in the early apoptotic death rate that results in poor survival of cells after treatment, as clearly demonstrated by flow cytometry experiments. Overall, these results show that metformin may not only inhibit the growth of HT29 cells, but also induces cell apoptosis. These considerations were supported by the analysis of key factors involved in the apoptotic process as APAF-1, Cleaved PARP-1, and caspase- 3 active. Cell apoptosis is activated in response to both intrinsic and extrinsic pathways. Drug therapies that induce apoptosis cause DNA damage-induced and p53-regulated release of cytochrome-c from mitochondria. In turn, cytochrome-c binds to apoptosis-activating factor-1 (APAF-1), resulting in the activation of caspase 9, which is followed by the activation of effector caspases including caspase 3. Following ligation, death receptors signal cell death by inducing a death-inducing signaling complex composed of the cytoplasmic adapter protein FADD (Fas-associated death domain) and caspase 8 . Activated caspase 8 can activate caspase 3 both directly and indirectly by truncation of Bid [21]. Metformin has been shown to induce cancer cell apoptosis through both the intrinsic and extrinsic pathways [22]. In this study, we observed that caspase 3 active, Cleaved PARP-1, and APAF-1 expressions were higher in treated cells with respect to untreated cells in a statistically significant manner, already in the lowest metformin concentration used $(10 \mathrm{mmol} / \mathrm{L})$. Previously, metformin at $20 \mathrm{mmol} / \mathrm{L}$ has been shown effective against breast cancer [23], melanoma [24], and gastric cancer [25]. The concentration of metformin administered to type 2 diabetic patients is approximately 30-60 $\mu \mathrm{mol} / \mathrm{L}$ [26]. Thus, the doses of metformin that were shown effective against cancer cells are approximately 300-600 fold (around $20 \mathrm{mmol} / \mathrm{L}$ ) greater than the dose routinely administered for diabetic disorders, and about 1000 times higher than what is used in common practice [27]. In this study, we used also a low dose of metformin $(10 \mathrm{mmol} / \mathrm{L})$ in order to establish whether the drug induces apoptosis at doses that avoid toxic side effects to cells. The results confirmed that metformin was effective even at low doses, whereas higher metformin concentrations, being toxic, will lead to apoptosis. Furthermore, for anticancer metformin translational research the metformin concentration obviously needs to change. Elevated levels of autophagic marker expression were observed in treated cells. This result may have controversial interpretations, in fact recent studies suggest that autophagy plays a dual role in determining cell fate, which means that it could be a survival mechanism or induce programmed cell death, depending on different cellular stresses. In some conditions, the activation of autophagy provides cell protection presumably by eliminating dysfunctional organelles and proteins and maintaining the energy balance. To a large extent, the cytoprotective function of autophagy appears to be a consequence of the fact that autophagy induction inhibits apoptosis through a cross-talk between autophagy and apoptosis regulatory pathways. On the other hand, autophagy is also considered a type of cell death program [28]. It is well known that there are 3 types of cell death. Necrosis, a type of unprogrammed cell death, evokes cellular inflammation reaction by immunological activation and subsequently leads to cell death in neighbor cells. Apoptosis, which is programmed cell death type I, is characterized by the formation of chromatin condensation, DNA fragmentation, and apoptotic bodies. Cell death by overactivated autophagy has been referred to as programmed cell death type II [29]. Upregulation of autophagy has been shown to lead to cell death in order to eliminate damaged or 
abnormal cells. It would seem reasonable to expect that cytotoxic autophagy should be a consequence of higher levels or a more prolonged process of cellular self-digestion rather than of cytoprotective autophagy. However, there is no explicit experimental evidence suggesting that cytotoxic autophagy is uniquely different from cytoprotective autophagy. In general, depending on the type of the tumor and stimuli, as well as the extent of DNA damage, autophagy can have both cytoprotective and cytotoxic functions [30].

Another point to be discussed is the response of NRF-2 protein to metformin treatment; the NRF-2 expression profile is negatively regulated by the drug in a dose- and time-dependent manner. This finding is very intriguing as there are researches geared towards defining the boundaries between NRF-2 positive and negative effects in cancer, which aim to establish a precise rationale for undertaking NRF-2 therapeutic targeting. The main function of the transcription factor NRF-2 is to activate the cellular antioxidant response by inducing the transcription of several genes to protect cells from the effects of exogenous and endogenous insults such as xenobiotics and oxidative stress [31]. As a result, NRF-2 has been typically regarded as a cytoprotective transcription factor and is considered as the main defense mechanism of the cell and a major regulator of cell survival. Thus, NRF-2 has been traditionally deemed to be a tumor suppressor. Indeed, NRF-2-deficient mice are more sensitive to carcinogenesis $[32,33]$ and NRF-2 loss has been linked to enhanced metastatic potential $[34,35]$. However, in the past few years, increasing evidence suggest that NRF-2 activation might not be beneficial in all cancer types and stages. In fact, NRF-2 promotes survival not only of normal cells but also of cancer cells, supporting the hypothesis that NRF-2 activation in malignant cells might sustain the evolution of the disease. The identification of a 'dark side' of NRF-2 [36,37] has generated controversy because it is still unclear whether NRF-2 acts as a tumor suppressor or as an oncogene [36,38]. Indeed, since oxidative stress is involved in the initiation of cancer, the anti-oxidative function of NRF-2 may play an anticancer role and may be useful in cancer chemoprevention. NRF-2 hyperactivation in tumors creates an environment that may favor the survival of cancer cells by protecting them from excessive oxidative stress, chemotherapeutic agents, or radiotherapy $[31,39,40]$. Indeed, in human tumor samples and cell lines, constitutive NRF-2 activation increases the expression of some genes involved in drug metabolism, thereby sustaining resistance to chemotherapeutic drugs and radiotherapy [41]. NRF-2 can play an important role in chemoresistance, preventing the intracellular accumulation of drugs in cancer cells and subsequently protecting cells from apoptosis [42]. These literature data are in line with our observation that metformin induces an increase of apoptotic key-factors and reduces the nuclear translocation of NRF-2 protein. To our knowledge, this is the first study in which the effect of metformin on NRF-2 protein is investigated, and it may provide an opportunity to study new molecules capable of interfering with the binding and activation of the NRF-2 pathway. Moreover, NF- $\mathrm{kB}$ expression pattern is drastically affected by metformin treatment, in fact, treated cells showed a significant decrease in NF- $\mathrm{KB}$ protein levels. In addition, the protein was present only in the cytoplasmic compartment, whereas, in untreated cells NFKB was expressed at the nuclear level. Several lines of evidence have shown that the transcription factor, nuclear factor-kappa $B$ (NF-kB), is a critical determinant, as it regulates a variety of pathophysiological processes, such as inflammation, cell survival, proliferation, invasion, apoptosis, differentiation, and chemo-resistance in different tumor cells, including colorectal $[43,44]$. Therefore, pharmacologically-safe antitumor agents with potential to influence the tumor microenvironment and inhibit NF- $\mathrm{kB}$ signaling activation may enhance chemo-sensitivity and reduce metastasis of tumor cells, thus providing a promising approach for the prevention or treatment of tumors. Moreover, several studies are posing NF- $\mathrm{kB}$ as a key regulator in the cross-talk among the pathways leading to type 2 diabetes mellitus, inflammatory bowel diseases, and colorectal cancer [20]. Actually, various carcinogens, growth factors, inflammatory stimuli including microbiota and pro-oxidants activate the transcription factor NF- $\mathrm{kB}$ which plays a central role in inflammation and is mostly expressed in cancers [45]. NF- $\mathrm{kB}$ plays a pivotal role in linking chronic inflammation to cancer development through its ability to upregulate several inflammatory and tumor promoting cytokines such as IL-6, IL- $1 \alpha$, and TNF- $\alpha$, as well as survival genes 
such as BCL2 and BCLXL [46]. In addition, NF- $\mathrm{KB}$ promotes the epithelial-mesenchymal transition (EMT), through activation of snail and twist [47] in the microenvironment, and the expression of inflammatory cytokines. Moreover, NF- $\mathrm{KB}$ seems to be involved in tumor-associated macrophage (TAM) recruitment and acts in cancer-associated fibroblasts (CAF), by promoting the expression of a proinflammatory gene signature, which is important for macrophage recruitment, neovascularization, and tumor growth, which are abolished when NF- $\mathrm{kB}$ is inhibited [48] This study shows that metformin has an antiproliferative effect related to changes in the expression of NRF-2/NF- $k B$ pathways, as well as an apoptotic effect on human colon cancer cells. Although further studies are needed to elucidate the detailed correlation between these processes, it can be hypothesized that metformin, which is already widely used in humans as antidiabetic drug, might be a promising candidate for the prevention or treatment of colorectal cancer. On the other hand, type 2 diabetes mellitus, colorectal cancer, and inflammatory bowel diseases are commonly occurring interrelated clinical problems. They share a common basis influenced by disease-related inflammation, a process characterized by upregulation of expression of common inflammatory cytokines along with TGF $\beta, T N F \alpha, N F-\kappa B$, ROS and other signaling molecules, leading to an imbalance in the intestinal microbiota. The intersection and the converging of all these molecular pathways constitute a cross-talk, which affects the pathogenesis of the above-mentioned chronic diseases. A treatment that can interfere with this cross-talk could be a novel therapeutic target of interest in managing the three diseases. The authors are aware that some aspects of the present work are still critical; these preliminary data will be refined in more sophisticated, preplanned experiments.

\section{Materials and Methods}

\subsection{Cell Culture}

The human colon carcinoma cell line HT29 was obtained from the American Type Culture Collection and was grown in Dulbecco's modified Eagle's medium supplemented with $10 \%$ fetal bovine serum, glutamine $(4 \mathrm{mM})$, and penicillin $(100 \mathrm{U} / \mathrm{mL}) /$ streptomycin $(100 \mathrm{~g} / \mathrm{mL})$. Cell cultures were maintained at $37{ }^{\circ} \mathrm{C}$ in $5 \% \mathrm{CO}_{2}$ and $95 \%$ air. HT29 cells were plated at the approximate density of $1 \times 10^{6}$ cells / dish in $10 \mathrm{~cm}^{2}$ culture dishes, $4 \times 10^{4}$ cells / well in two-well chamber glass slides, and $1 \times 10^{4}$ cell/well in 96-well tissue culture plates. When cells reached approximately $60 \%$ confluence, the medium was replaced with serum-free cell medium containing different concentrations of metformin $(0,10,25$, and $50 \mathrm{mmol} / \mathrm{L})$ and the cells were cultured for 24 and $48 \mathrm{~h}$ at $37^{\circ} \mathrm{C}$ in $5 \%$ $\mathrm{CO}_{2}$ and $95 \%$ air. The cells were trypsinized with $0.25 \%$ trypsin and $0.2 \mathrm{~g} / \mathrm{L}$ EDTA, and harvested for further studies. Metformin was purchased from Sigma Aldrich (Saint Louis, MO, USA; PHR 1084) and was dissolved in sterile water at a stock dose of $1 \mathrm{M}$ for further application.

\subsection{Cell Counting}

Cells were seeded at a density of 20,000/well and were counted at day one, two, and three after plating. For counting, cells were detached from the wells by washing in a $0.25 \%$ trypsin and $0.2 \mathrm{~g} / \mathrm{L}$ EDTA solution. Thereafter, $1 \mathrm{~mL}$ normal culture medium was added to stop the trypsinization; a $500 \mu \mathrm{L}$ cell suspension, to which $70 \mu \mathrm{L}$ trypan blue was added, then, was transferred into a Burker chamber for cell counting. The number of cells, expressed as number $/ \mathrm{mL}$, was determined by two blinded observers.

\subsection{Western Blot Analysis}

Whole cell lysates were obtained from cultured cells, as described above, and extracted with hypotonic buffer (50 mM Tris-Cl, pH 7.8, containing $1 \%$ Nonidet P40, $140 \mathrm{mM} \mathrm{NaCl}, 0.1 \%$ SDS, $0.1 \% \mathrm{Na}$ deoxycholate, $1 \mathrm{mM} \mathrm{Na}_{3} \mathrm{VO}_{4}$, and freshly added protease inhibitor cocktail). Lysates were then cleared by centrifugation for $15 \mathrm{~min}$ in a refrigerated centrifuge at maximum speed, and then were immediately boiled in SDS sample buffer. Forty milligrams of protein extract from each treatment condition was 
electrophoresed on SDS-PAGE and transferred to nitrocellulose membranes. The membranes were blocked with 3\% dry milk and 2\% BSA in PBS-T, and incubated with the following antibodies (diluted 1:1000 overnight at $4{ }^{\circ} \mathrm{C}$ under agitation), mouse anti-human APAF-1, rabbit anti-human MAPLC3, mouse anti-human NF-KB (Santa Cruz), mouse anti-human PARP-1 cleaved (Cell Signaling, Beverly, MA, USA), mouse anti-human NRF-2 (Abcam, Cambridge, UK), and mouse anti-human Ki-67 (DAKO, Glostrup, Denmark). After washing, the membranes were incubated with secondary HPR-conjugated goat anti-mouse IgG antibody (1:5000) or HPR-conjugated goat anti-rabbit IgG antibody (1:5000) (Thermo scientific, Waltham, MA, USA) for $30 \mathrm{~min}$ at room temperature. Immunoreactive proteins were detected with ECL (Amersham, Little Chalfont, UK). Anti-mouse- $\beta$ tubulin (Sigma Aldrich) was used as loading control. Densitometry analysis was performed using a KODAK (Rochester, NY, USA) Image Station 440 cf system), and semi-quantitative analysis was performed with NIH Image J software. For each sample and marker, the band intensities were normalized to $\beta$-tubulin, and results were expressed as the normalized treatment to control ratio.

\subsection{Evaluation of Immunofluorescence by Confocal Microscopy}

Cells were cultured in two-well chamber glass slides which were used for immunofluorescence analysis to evaluate the expression of MAPLC3, APAF-1, PARP-1 cleaved, NRF-2, NF-kB, and Ki-67 proteins. Monolayered cells were fixed in $4 \%$ paraformaldehyde in PBS for $10 \mathrm{~min}$. After a treatment with 3\% BSA in PBS for 30 min at room temperature, they were incubated with the primary antibodies (mouse anti-human APAF-1, rabbit anti-human MAPLC3, mouse anti-human caspase-3 active, mouse anti- human NF- $k B$, Santa Cruz mouse anti-human PARP-1 cleaved, mouse anti-human NRF-2, Abcam mouse anti-human Ki-67, and DAKO), and diluted 1:25 in PBS containing 3\% BSA for $1 \mathrm{~h}$ at room temperature. After washing in PBS, the samples were incubated for $1 \mathrm{~h}$ at room temperature with the secondary antibodies diluted by 1:20 in PBS containing 3\% BSA (sheep anti-mouse FITC conjugated, goat anti-rabbit TRITC conjugated, Sigma Aldrich). After washing in PBS and in $\mathrm{H}_{2} \mathrm{O}$, the samples were counterstained with $1 \mathrm{mg} / \mathrm{mL}$ DAPI in $\mathrm{H}_{2} \mathrm{O}$ and then mounted with antifading medium (0.21 M DABCO and 90\% glycerol in $0.02 \mathrm{M}$ Tris, $\mathrm{pH} 8.0)$. Negative control samples were not incubated with the primary antibody. The confocal imaging was performed under a Leica TCS SP2 AOBS confocal laser scanning microscope. Excitation and detection of the samples were carried out in sequential mode to avoid overlapping of signals. Sections were scanned with laser intensity, confocal aperture, gain, and black level settings kept constant for all samples. Optical sections were obtained at increments of $0.3 \mathrm{~mm}$ in the $z$-axis and were digitized with a scanning mode format of $512 \times 512$ or $1024 \times 1024$ pixels and 256 grey levels. The confocal serial sections were processed with the Leica LCS software to obtain three-dimensional projections. Image rendering was performed by Adobe Photoshop software. The original green fluorescent confocal images were converted to greyscale and median filtering was performed. An intensity value between 0 (black) and 255 (white) was assigned to each pixel. Background fluorescence was subtracted and immunofluorescence intensity (IF) was calculated as the average for each selected area. The fluorescence intensity at the selected areas, linearly correlated with the number of pixels, and was quantitatively analyzed using the standard imaging analysis software of an NIS-Elements System. Each sample was assigned a code number and score, referred to as the Immunofluorescence Intensity Score (IFIS), which was determined by an observer who was blind to tissue groups during the analysis [49].

\subsection{Flow Cytometry Analysis}

The apoptotic status of HT-29 cells was evaluated by measuring the exposure of phosphatidylserine on the cell membranes using Annexin V-fluorescein isothiocyanate (Annexin V-FITC) and propidium iodide (PI) staining [50]. The BD Pharmingen Annexin V-FITC Apoptosis Detection Kit I (BD Biosciences, Frankrin Lakes, NJ, USA) was used for the apoptosis assay. HT-29 cells were plated in a 24 -well plate $\left(1 \times 10^{6}\right.$ cells $\left.\mathrm{mL}^{-1}\right)$, and after a $24 \mathrm{~h}$ incubation, the cells were treated with graded concentrations of metformin $(0,10,25$, and $50 \mathrm{mmol} / \mathrm{L})$ for 24 and $48 \mathrm{~h}$, 
and harvested. After centrifugation, the cell pellets were washed twice with cold phosphate-buffered saline (PBS: $137 \mathrm{mM} \mathrm{NaCl}, 2.7 \mathrm{mM} \mathrm{KCl}, 10 \mathrm{mM} \mathrm{Na}_{2} \mathrm{HPO}_{4}, \mathrm{pH} 7.4$ ) and suspended in $100 \mu \mathrm{L}$ of $1 \times$ binding buffer (10 mM Hepes/ $\left.\mathrm{NaOH}, 140 \mathrm{mM} \mathrm{NaCl}, 2.5 \mathrm{mM} \mathrm{CaC}_{12}, \mathrm{pH} 7.4\right)$. The cells were incubated with $5 \mu \mathrm{L}$ Annexin V-FITC and $10 \mu \mathrm{L}$ PI at room temperature for $15 \mathrm{~min}$ in the dark. After the incubation, $400 \mu \mathrm{L}$ of $1 \times$ binding buffer was added to each tube. The cells were analyzed immediately by Epics XL-MCL Flow Cytometry (Beckman Coulter, Cassina de Pecchi, Italy).

\subsection{Statistical Analysis}

All experiments were performed in triplicate. Data were expressed as means \pm standard deviation. Statistical comparisons of results were made using analysis of variance (ANOVA). Significant differences $(p<0.05)$ between the means of control and metformin treated cells were analyzed by a Student's $t$-test.

Author Contributions: P.S. and L.R. conceived and designed the experiments; P.S. and M.B. performed the experiments; P.S. and S.M. analyzed the data; C.P. and F.M. contributed reagents/materials/analysis tools; P.S. and L.R. wrote the paper.

Acknowledgments: The study was supported by funds of the Associazione per la Ricerca sui Tumori Intestinali (ARTI) and Fondazione Cassa di Risparmio di Vignola. The authors wish to thank the Centro Interdipartimentale Grandi Strumenti (C.I.G.S.) of the University of Modena and Reggio Emilia, for software, instrument availability, and assistance.

Conflicts of Interest: The authors declare no conflicts of interest.

\section{References}

1. Siegel, R.L.; Miller, K.D.; Stacey, A.; Fedewa, S.A.; Ahnen, D.J.; Meester, R.G.S.; Barzi, S.; Jemal, A. Cancer statistics, 2017. CA Cancer J. Clin. 2017, 67, 7-30. [CrossRef] [PubMed]

2. Anderson, W.F.; Umar, A.; Brawley, O.W. Colorectal carcinoma in black and white race. Cancer Metastab. Rev. 2003, 22, 67-82. [CrossRef]

3. Das, D.; Arber, N.; Jankowski, J.A. Chemoprevention of colorectal cancer. Digestion 2007, 76, 51-67. [CrossRef] [PubMed]

4. Gupta, R.A.; Dubois, R.N. Colorectal cancer prevention and treatment by inhibition of cyclooxygenase-2. Nat. Rev. Cancer 2001, 1, 11-21. [CrossRef] [PubMed]

5. Psaty, B.M.; Furberg, C.D. COX-2 inhibitors-Lessons in drug safety. N. Engl. J. Med. 2005, 352, 1133-1135. [CrossRef] [PubMed]

6. Meyskens, F.L., Jr; McLaren, C.E.; Pelot, D.; Fujikawa-Brooks, S.; Carpenter, P.M.; Hawk, E.; Kelloff, G.; Lawson, M.J.; Kidao, J.; McCracken, J.; et al. Difluoromethylornithine plus sulindac for the prevention of sporadic colorectal adenomas: A randomized placebo-controlled, double-blind trial. Cancer Prev. Res. 2008, 1, 32-38. [CrossRef] [PubMed]

7. Limburg, P.J.; Anderson, K.E.; Johnson, T.W; Jacobs, D.R., Jr; Lazovich, D.; Hong, C.P.; Nicodemus, K.K.; Folsom, A.R. Diabetes mellitus and subsite-specific colorectal cancer risks in the Iowa Women's Health Study. Cancer Epidemiol. Biomark. Prev. 2005, 14, 133-137. [CrossRef]

8. Larsson, S.C.; Giovannucci, E.; Wolk, A. Diabetes and colorectal cancer incidence in the cohort of Swedish men. Diabetes Care 2005, 28, 1805-1807. [CrossRef] [PubMed]

9. Giovannucci, E.; Ascherio, A.; Rimm, E.B.; Colditz, G.A.; Stampfer, M.J.; Willett, W.C. Physical activity, obesity, and risk for colon cancer and adenoma in men. Ann. Intern. Med. 1995, 122, 327-334. [CrossRef] [PubMed]

10. Frezza, E.E.; Wachtel, M.S.; Chiriva-Internati, M. Influence of obesity on the risk of developing colon cancer. Gut 2006, 55, 285-291. [CrossRef] [PubMed]

11. Witters, L.A. The blooming of the French lilac. J. Clin. Investig. 2001, 108, 1105-1107. [CrossRef] [PubMed]

12. Bodmer, M.; Meier, C.; Krähenbühl, S.; Jick, S.S.; Meier, C.R. Metformin, sulfonylureas, or other antidiabetes drugs and the risk of lactic acidosis or hypoglycemia: A nested case-control analysis. Diabetes Care 2008, 31, 2086-2091. [CrossRef] [PubMed] 
13. Shaw, R.J.; Lamina, K.A.; Vasquez, D.; Koo, S.H.; Bardeesy, N.; Depinho, R.A.; Montminy, M.; Cantley, L.C. The kinase LKB1 medited glucose homeostasis in liver and therapeutic effects of metformin. Science 2005, 310, 1642-1646. [CrossRef] [PubMed]

14. Libby, G.; Donnelly, L.A.; Donnan, P.T.; Alessi, D.R.; Morris, A.D.; Evans, J.M. New users of metformin are at low risk of incident cancer: A cohort study among people with type 2 diabetes. Diabetes Care 2009, 32, 1620-1625. [CrossRef] [PubMed]

15. Currie, C.J.; Poole, C.D.; Gale, E.A. The influence of glucose-lowering therapies on cancer risk in type 2 diabetes. Diabetologia 2009, 52, 1766-1777. [CrossRef] [PubMed]

16. Alimova, I.N.; Liu, B.; Fan, Z.; Edgerton, S.M.; Dillon, T.; Lind, S.E.; Thor, A.D. Metformin inhibits breast cancer cell growth, colony formation and induces cell cycle arrest in vitro. Cell Cycle 2009, 8, 909-915. [CrossRef] [PubMed]

17. Ben Sahra, I.; Laurent, K.; Loubat, A.; Giorgetti-Paraldi, S.; Colosetti, P.; Auberger, P.; Tanti, J.F.; Le Marchand-Brustel, Y.; Bosi, F. The antidiabetic drug metformin exerts an antitumoral effect in vitro and in vivo through a decrease of cyclin D1 level. Oncogene 2008, 27, 3576-3586. [CrossRef] [PubMed]

18. Hirsch, H.A.; Iliopoulos, D.; Tsichlis, P.N.; Sruhl, K. Metformin selectively targets cancer stem cells, and acts together with chemotherapy to block tumor growth and prolong remission. Cancer Res. 2009, 69, 7507-7511. [CrossRef] [PubMed]

19. Song, C.W.; Lee, H.; Dings, R.P.; Williams, B.; Powers, J.; Santos, T.D.; Cho, B.H.; Park, H.J. Metformin kills and radiosensitizes cancer cells and preferentially kills cancer stem cells. Sci. Rep. 2012, 2, 362. [CrossRef] [PubMed]

20. Jurjus, A.; Eid, A.; Al Kattar, S.; Zeenny, M.N.; Gerges-Geagea, A.; Haydar, H.; Hilal, A.; Oueidat, D.; Matar, M.; Tawilah, J.; et al. Inflammatory bowel disease, colorectal cancer and type 2 diabetes mellitus: The links. BBA Clin. 2016, 5, 16-24. [CrossRef] [PubMed]

21. Oudejans, J.J.; Muris, J.J.; Meijer, C.J. Inhibition of caspase 9 and notcaspase 8 mediated apoptosis may determine clinical response tochemotherapy in primary nodal diffuse large B-cell lymphomas. Cell Cycle 2005, 4, 526-528. [CrossRef] [PubMed]

22. Wang, L.W.; Li, Z.S.; Zou, D.W.; Jin, Z.D.; Gao, J.; Xu, G.M. Metformin induces apoptosis of pancreatic cancer cells. World J. Gastroenterol. 2008, 14, 7192-7198. [CrossRef] [PubMed]

23. Zakikhani, M.; Dowling, R.; Fantus, I.G.; Sonenberg, N.; Pollak, M. Metformin is an AMP kinase-dependent growth inhibitor for breast cancer cells. Cancer Res 2006, 66, 10269-10273. [CrossRef] [PubMed]

24. Janjetovic, K.; Harhaji-Trajkovic, L.; Misirkic-Marjanovic, M.; Vucicevic, L.; Stevanovic, D.; Zogovic, N.; Sumarac-Dumanovic, M.; Micic, D.; Trajkovic, V. In vitro and in vivo anti-melanoma action of metformin. Eur. J. Pharmacol. 2011, 668, 373-382. [CrossRef] [PubMed]

25. Kato, K.; Gong, J.; Iwama, H.; Kitanaka, A.; Tani, J.; Miyoshi, H.; Nomura, K.; Mimura, S.; Kobayashi, H.; Aritomo, Y.; et al. The antidiabetic drug metformin inhibits gastric cancer cell proliferation in vitro and in vivo. Mol. Cancer Ther. 2012, 11, 549-560. [CrossRef] [PubMed]

26. Martin-Castillo, B.; Vazquez-Martin, A.; Oliveras-Ferraros, C.; Menendez, J.A. Metformin and cancer: Doses, mechanisms and the dandelion and hormetic phenomena. Cell Cycle 2010, 9, 1057-1064. [CrossRef] [PubMed]

27. He, L.; Wondisford, F.E. Metformin action: Concentration matters. Cell Metab. 2015, 21, 159-162. [CrossRef] [PubMed]

28. Gozuacik, D.; Kimchi, A. Autophagy and cell death. Curr. Top. Dev. Biol. 2007, 78, 217-245. [CrossRef] [PubMed]

29. Mizushima, N.; Ohsumi, Y.; Yoshimori, T. Autophagosome formation in mammalian cells. Cell Struct. Funct. 2002, 27, 421-429. [CrossRef] [PubMed]

30. Mathew, R.; Karantza-Wadsworth, V.; White, E. Role of autophagy in cancer. Nat. Rev. Cancer 2007, 7, 961-967. [CrossRef] [PubMed]

31. Motohashi, H.; Yamamoto, M. Nrf2-Keap1 defines a physiologically important stress response mechanism. Trends Mol. Med. 2004, 10, 549-557. [CrossRef] [PubMed]

32. Ramos-Gomez, M.; Dolan, P.M.; Itoh, K.; Yamamoto, M.; Kensler, T.W. Interactive effects of Nrf2 geno-type and oltipraz on benzo[a]pyrene-DNA adducts and tumor yield in mice. Carcinogenesis 2003, 24, 461-467. [CrossRef] [PubMed] 
33. Iida, K.; Itoh, K.; Kumagai, Y.; Oyasu, R.; Hattori, K.; Kawai, K.; Shimazui, T.; Akaza, H.; Yamamoto, M. Nrf2 is essential for the chemopreventive efficacy of oltipraz against urinary bladder carcinogenesis. Cancer Res. 2004, 64, 6424-6431. [CrossRef] [PubMed]

34. Satoh, H.; Moriguchi, T.; Taguchi, K.; Takai, J.; Maher, J.M.; Suzuki, T.; Winnard, P.T., Jr.; Raman, V.; Ebina, M.; Nukiwa, T.; et al. Nrf2-deficiency creates a responsive microenvironment for metastasis to the lung. Carcinogenesis 2010, 31, 1833-1843. [CrossRef] [PubMed]

35. Rachakonda, G.; Sekhar, K.R.; Jowhar, D.; Samson, P.C.; Wikswo, J.P.; Beauchamp, R.D.; Datta, P.K.; Freeman, M.L. Increased cell migration and plasticity in Nrf2-deficient cancer cell lines. Oncogene 2010, 29, 3703-3714. [CrossRef] [PubMed]

36. Lau, A.; Villeneuve, N.F.; Sun, Z.; Wong, P.K.; Zhang, D.D. Dual roles of Nrf2 in cancer. Pharmacol. Res. 2008, 58, 262-270. [CrossRef] [PubMed]

37. Wang X, J.; Sun, Z.; Villeneuve, N.F.; Zhang, S.; Zhao, F.; Li, Y.; Chen, W.; Yi, X.; Zheng, W.; Wondrak, G.T.; et al. Nrf2 enhances resistance of cancer cells to chemotherapeutic drugs, the dark side of Nrf2. Carcinogenesis 2008, 29, 1235-1243. [CrossRef] [PubMed]

38. Sporn, M.B.; Liby, K. NRF2 and cancer: The good, the bad and the importance of context. Nat Rev Cancer 2012, 12, 564-571. [CrossRef] [PubMed]

39. Hayes, J.D.; McMahon, M.; Chowdhry, S.; Dinkowa-Kostova, A.T. Cancer chemoprevention mechanisms mediated through the Keap1-Nrf2 pathway. Antioxid. Redox Signal. 2010, 13, 1713-1748. [CrossRef] [PubMed]

40. Zhang, P.; Singh, A.; Yegnasubramanian, S.; Esopi, D.; Kombairaju, P.; Bodas, M.; Wu, H.; Bova, S.G.; Biswal, S. Loss of Kelch-like ECH-associated protein 1 function in prostate cancer cells causes chemoresistance and radioresistance and promotes tumor growth. Mol. Cancer Ther. 2010, 9, 336-346. [CrossRef] [PubMed]

41. Akhdar, H.; Loyer, P.; Rauch, C.; Corlu, A.; Guillouzo, A.; Morel, F. Involvement of Nrf2 activation in resistance to 5-fluorouracil in human colon cancer HT-29 cells. Eur. J. Cancer 2009, 45, 2219-2227. [CrossRef] [PubMed]

42. Menegon, S.; Columbano, A.; Giordano, S. The Dual Roles of NRF2 in Cancer. Trends Mol. Med. 2016, 22, 578-593. [CrossRef] [PubMed]

43. Caamaño, J.; Hunter, C.A. NF-kappaB family of transcription factors: Central regulators of innate and adaptive immune functions. Clin. Microbiol. Rev. 2002, 15, 414-429. [CrossRef] [PubMed]

44. Viennois, E.; Chen, F.; Merlin, D. NF-кB pathway in colitis-associated cancers. Transl. Gastrointest. Cancer 2013, 2, 21-29. [CrossRef] [PubMed]

45. Hayden, M.S.; Ghosh, S. Shared principles in NF-kappaB signaling. Cell 2008, 132, 344-362. [CrossRef] [PubMed]

46. Ben-Neriah, Y.; Karin, M. Inflammation Meets Cancer, with NF-[Kappa] B as the Matchmaker. Nat. Immunol. 2011, 19, 715-723. [CrossRef] [PubMed]

47. Min, C.; Eddy, S.F.; Sherr, D.H.; Sonenshein, G.E. NF-kB and Epithelial to Mesenchymal Transition of Cancer. J. Cell. Biochem. 2008, 104, 733-744. [CrossRef] [PubMed]

48. Erez, N.; Truitt, M.; Olson, P.; Arron, S.T.; Hanahan, D. Cancer-Associated Fibroblasts are Activated in Incipient Neoplasia to Orchestrate Tumor-Promoting Inflammation in an NF-kB-Dependent Manner. Cancer Cell 2010, 17, 135-147. [CrossRef] [PubMed]

49. Sena, P.; Mariani, F.; Mancini, S.; Benincasa, M.; Magnani, G.; Pedroni, M.; Palumbo, C.; Roncucci, L. Autophagy is upregulated during colorectal carcinogenesis, and in DNA microsatellite stable carcinomas. Oncol. Rep. 2015, 34, 3222-3230. [CrossRef] [PubMed]

50. Eray M, M.; Mättö, N.; Kaartinen, L.; Andersson, L.; Pelkonen, J. Flow cytometric analysis of apoptotic subpopulations with a combination of Annexin V-FITC, propidium iodide, and SYTO 17. Cytometry 2001, 43, 134-142. [CrossRef]

(C) 2018 by the authors. Licensee MDPI, Basel, Switzerland. This article is an open access article distributed under the terms and conditions of the Creative Commons Attribution (CC BY) license (http:/ / creativecommons.org/licenses/by/4.0/). 